\title{
Chlorophyllin e4 is a novel photosensitizer against human bladder cancer cells
}

\author{
BIN LI ${ }^{1}$, ZHIMING WU ${ }^{1}$, WENZHI LI ${ }^{1}$, GUOJIN JIA ${ }^{1}$, JIANCHENG LU $^{1}$, JIE FANG $^{2}$ and GANG CHEN ${ }^{1}$ \\ ${ }^{1}$ Department of Urology, Jin Shan Hospital, Fudan University; \\ ${ }^{2}$ Department of Urology, Hua Shan Hospital, Fudan University, Shanghai, P.R. China
}

Received November 20, 2011; Accepted December 19, 2011

DOI: 10.3892/or.2012.1656

\begin{abstract}
The aim of the study was to investigate the photodynamic effect of the novel photosensitizer chlorophyllin e4 against human bladder cancer cells. T24 and 5637 bladder cancer cell lines were incubated with chlorophyllin e4 and irradiated with a $650-\mathrm{nm}$ laser light. The controls included cells treated with chlorophyllin e4 but without light as well as cells exposed to laser light without chlorophyllin e4. Photocytotoxicity was monitored with MTT assay and apoptosis was measured by flow cytometry. In addition, confocal laser scanning microscopy was used to assess the subcellular localization of chlorophyllin e4. Chlorophyllin e4 exhibited significant photocytotoxicity in both T24 and 5637 cells, which resulted in a maximum of 82.43 and $85.06 \%$ cell death, respectively. Treatment with chlorophyllin e4 or laser light alone did not induce cytotoxicity. In addition, chlorophyllin e4-mediated PDT induced a significantly higher percentage of apoptosis in T24 and 5637 cells compared to the control groups $(\mathrm{p}<0.01)$. Moreover, confocal laser scanning microscopy revealed that chlorophyllin e4 co-localized with mitochondria in both cell lines. In conclusion, the remarkable photocytotoxicity, natural abundance and inexpensive composition of chlorophyllin e4 suggest that this compound may be a novel, effective photosensitizer for the treatment of human superficial bladder cancer.
\end{abstract}

\section{Introduction}

Bladder cancer is the ninth most common malignant disease in the world (1). It is estimated that 68810 Americans (51230 male and 17580 female) were diagnosed with bladder tumors in 2008, which led to 14100 deaths (9950 male and 4150 female) (2). Patients with superficial bladder cancer usually have one

Correspondence to: Dr Gang Chen, Department of Urology, Jin Shan Hospital, Fudan University, 391 Jinyidong Road, Shanghai 200540, P.R. China

E-mail: 15216650243@139.com

Key words: bladder cancer, chlorophyllin, fluorescence, photodynamic therapy, photosensitizer or more recurrences after their first treatment, and approximately $15-20 \%$ of these tumors progress to invasive bladder cancer (3-5). The conventional therapy for superficial bladder cancer is based mainly on transurethral resection combined with post-operational chemo- or immunotherapy. However, the resistance to chemo- or immunotherapy, severe irritation symptoms, decrease of vesical compliance, and even bladder contracture are still unresolved complications of therapy (6).

Photodynamic therapy (PDT) has been investigated as a minimally invasive and promising modality for superficial bladder cancer (7). PDT combines a photosensitizer (PS) and laser light of the correct wavelength to be absorbed by the PS as a method for damaging cellular components, which ultimately leads to cell death (8). The anatomical features of the bladder make it one of the most suitable organs for PDT, since access by endoscopy is relatively easy.

We have recently developed a novel PS of natural origin called chlorophyllin e4. This compound is a chlorophyll derivative extracted from traditional Chinese medicine excrementum bombycis. Chlorophyllin e4 is a chemically pure compound and is synthesized according to our patent specifications. In this study, we present the effects and mechanism of chlorophyllin e4-mediated PDT against the human bladder T24 and 5637 cell lines.

\section{Materials and methods}

Preparation of chlorophyllin e4. Chlorophyllin e4 was synthesized according to our patent specifications (No. ZL 200510024984.8). First, we dissolved $200 \mathrm{~g}$ of crude chlorophyll in $800 \mathrm{ml}$ of $80 \%$ acetone, added $30 \mathrm{ml}$ of $20 \% \mathrm{NaOH}$, and then hydrolyzed the preparation at $60^{\circ} \mathrm{C}$ for $1 \mathrm{~h}$. We then carefully removed the acetone by distillation and cooled the mother liquor to room temperature. We next added $400 \mathrm{ml}$ of gasoline and shook vigorously for $5 \mathrm{~min}$ to remove the impurities. The wash was repeated 4 times. The liquid layer was then transferred to a glass beaker and the $\mathrm{pH}$ was slowly adjusted to $\mathrm{pH} 3.0 \mathrm{using} 18 \% \mathrm{HCl}$. The amorphous crystals of e6 were then precipitated. We separated the crystals by filtration and dried them in an electric ventilation oven at $70^{\circ} \mathrm{C}$. The solid was then subjected to chromatography in a column of silica gel and eluted with a 50:25:1 mixture of acetone: methanol: formic acid $(\mathrm{v} / \mathrm{v} / \mathrm{v})$. The final pure e6 product was a dark green amorphous crystal. 
We next dissolved $2 \mathrm{~g}$ of pure e6 in $100 \mathrm{ml}$ pyridine in a round bottom flask and added $20 \mathrm{ml}$ of $25 \% \mathrm{KOH}$ solution. The solution was refluxed in an oil bath at $120^{\circ} \mathrm{C}$ under nitrogen gas for $1 \mathrm{~h}$. The pyridine was then removed by distillation under reduced pressure. The mother liquor was poured into $200 \mathrm{ml}$ of distilled water, the $\mathrm{pH}$ was adjusted to $\mathrm{pH} 3.0$ using $18 \% \mathrm{HCl}$, and then the 4 crystal was precipitated. The chemical structure of chlorophyllin e4 and e6 are shown in Fig. 1. Chlorophyllin e4 was dissolved at different concentrations with RPMI-1640 medium and stored at $4{ }^{\circ} \mathrm{C}$ protected from visible light.

Tumor cell and culture conditions. The PDT effect of chlorophyllin e 4 was studied using the human bladder cancer T24 and 5637 cell lines, both purchased from the Shanghai Institutes of Biological Science. T24 and 5637 cells were grown in RPMI1640 medium supplemented with $10 \%$ fetal bovine serum (FBS) and $100 \mathrm{U} / \mathrm{ml}$ streptomycin and gentamycin (all purchased from Thermo Scientific, China) at $37^{\circ} \mathrm{C}$ in a fully humidified atmosphere with $5 \% \mathrm{CO}_{2}$.

Photosensitization. The T24 and 5637 cell lines were cultured in 96-well plates at a cell density of $1.0 \times 10^{4}$ cells in $100 \mu 1$ medium and allowed to reach approximately $80 \%$ confluence. Different concentrations of chlorophyllin e 4 were then added to the wells in a $100 \mu \mathrm{l}$ volume and incubated for an additional $4 \mathrm{~h}$. After incubation, the culture medium was changed and the cells were irradiated with 1 or $4 \mathrm{~J} / \mathrm{cm}^{2}$ of laser light at a wavelength of $650 \mathrm{~nm}$ and then incubated for an additional $12 \mathrm{~h}$ at $37^{\circ} \mathrm{C}$. Nine different treatment groups were established for the T24 cell line as follows: 3 control groups (blank control; cells treated with PS without laser light; and cells exposed to laser light without PS treatment) and 6 treatment groups (drug concentration and laser energy, respectively): $2.5 \mu \mathrm{g} / \mathrm{ml}$ with $1 \mathrm{~J} / \mathrm{cm}^{2} ; 5 \mu \mathrm{g} / \mathrm{ml}$ with $1 \mathrm{~J} / \mathrm{cm}^{2} ; 10 \mu \mathrm{g} / \mathrm{ml}$ with $1 \mathrm{~J} / \mathrm{cm}^{2} ; 2.5 \mu \mathrm{g} / \mathrm{ml}$ with $4 \mathrm{~J} / \mathrm{cm}^{2} ; 5 \mu \mathrm{g} / \mathrm{ml}$ with $4 \mathrm{~J} / \mathrm{cm}^{2}$; and $10 \mu \mathrm{g} / \mathrm{ml}$ with $4 \mathrm{~J} / \mathrm{cm}^{2}$. Nine different treatment groups were also established for the 5637 cell line as follows: the same 3 control groups as for the T2 4 cell line and 6 treatment groups (drug concentration and laser energy, respectively): $2 \mu \mathrm{g} / \mathrm{ml}$ with $1 \mathrm{~J} / \mathrm{cm}^{2} ; 1 \mu \mathrm{g} / \mathrm{ml}$ with $1 \mathrm{~J} / \mathrm{cm}^{2} ; 500 \mathrm{ng} / \mathrm{ml}$ with $1 \mathrm{~J} / \mathrm{cm}^{2} ; 2 \mu \mathrm{g} / \mathrm{ml}$ with $4 \mathrm{~J} / \mathrm{cm}^{2} ; 1 \mu \mathrm{g} / \mathrm{ml}$ with $4 \mathrm{~J} / \mathrm{cm}^{2}$; and $500 \mathrm{ng} / \mathrm{ml}$ with $4 \mathrm{~J} / \mathrm{cm}^{2}$. Each group had 4 replicates.

MTT assay. Cell survival was determined using the 3-(4, 5-dimethylthiazol-2-yl)-2, 5- diphenyltetrazolium bromide (MTT) (KeyGEN, China) assay according to the manufacturer's instructions. After photosensitization, $50 \mu \mathrm{l}$ MTT solution was added into each well and the cells were incubated for an additional $4 \mathrm{~h}$ to reduce MTT to formazan. The supernatant was then removed and $150 \mu$ dimethyl sulfoxide (DMSO) was added to dissolve formazan. After a 15-min incubation, the optical density (OD) of each sample was determined at $490 \mathrm{~nm}$.

Cell apoptosis. We used the Annexin V-FITC Apoptosis Detection kit (Invitrogen, China) to detect apoptosis of the cell lines from PDT. T24 and 5637 cells $\left(10^{5}\right.$ cells $\left./ 1 \mathrm{ml}\right)$ were incubated in a 24-well plate and allowed to reach approximately $80 \%$ confluence. Each group contained 8 replicates. Once the cells reached confluence, $500 \mu \mathrm{l}$ of $10 \mu \mathrm{g} / \mathrm{ml}$ and $2 \mu \mathrm{g} / \mathrm{ml}$ chlorophyllin e 4 solutions were added to the wells with T24 and
Table I. OD values of each group (T24 cells).

\begin{tabular}{lc}
\hline Group & OD value \\
\hline 1. Cell control & $0.69275 \pm 0.117557$ \\
$2.2 .5 \mu \mathrm{g} / \mathrm{ml}+1 \mathrm{~J} / \mathrm{cm}^{2}$ & $0.65050 \pm 0.040054^{\mathrm{a}}$ \\
$3.2 .5 \mu \mathrm{g} / \mathrm{ml}+4 \mathrm{~J} / \mathrm{cm}^{2}$ & $0.55400 \pm 0.045350^{\mathrm{b}}$ \\
$4.5 \mu \mathrm{g} / \mathrm{ml}+1 \mathrm{~J} / \mathrm{cm}^{2}$ & $0.34800 \pm 0.038323^{\mathrm{b}}$ \\
$5.5 \mu \mathrm{g} / \mathrm{ml}+4 \mathrm{~J} / \mathrm{cm}^{2}$ & $0.15668 \pm 0.028667^{\mathrm{b}}$ \\
$6.10 \mu \mathrm{g} / \mathrm{ml}+1 \mathrm{~J} / \mathrm{cm}^{2}$ & $0.14325 \pm 0.012500^{\mathrm{b}}$ \\
7. $10 \mu \mathrm{g} / \mathrm{ml}+4 \mathrm{~J} / \mathrm{cm}^{2}$ & $0.12175 \pm 0.011087^{\mathrm{b}}$ \\
8. PS alone group & $0.70550 \pm 0.050573^{\mathrm{a}}$ \\
9. Laser alone group & $0.71050 \pm 0.085823^{\mathrm{a}}$ \\
\hline
\end{tabular}

${ }^{\mathrm{a}} \mathrm{p}>0.05 ;{ }^{\mathrm{b}} \mathrm{p}<0.01$

Table II. OD values of each group (5637 cells).

\begin{tabular}{lc}
\hline Group & OD value \\
\hline 1. Cell control & $0.79175 \pm 0.170801$ \\
$2.500 \mathrm{ng} / \mathrm{ml}+1 \mathrm{~J} / \mathrm{cm}^{2}$ & $0.68575 \pm 0.063426^{\mathrm{a}}$ \\
$3.500 \mathrm{ng} / \mathrm{ml}+4 \mathrm{~J} / \mathrm{cm}^{2}$ & $0.66025 \pm 0.050116^{\mathrm{a}}$ \\
$4.1 \mu \mathrm{g} / \mathrm{ml}+1 \mathrm{~J} / \mathrm{cm}^{2}$ & $0.56125 \pm 0.144590^{\mathrm{b}}$ \\
$5.1 \mu \mathrm{g} / \mathrm{ml}+4 \mathrm{~J} / \mathrm{cm}^{2}$ & $0.33300 \pm 0.070347^{\mathrm{b}}$ \\
$6.2 \mu \mathrm{g} / \mathrm{ml}+1 \mathrm{~J} / \mathrm{cm}^{2}$ & $0.22800 \pm 0.043012^{\mathrm{b}}$ \\
$7.2 \mu \mathrm{g} / \mathrm{ml}+4 \mathrm{~J} / \mathrm{cm}^{2}$ & $0.11825 \pm 0.013022^{\mathrm{b}}$ \\
8. PS alone group & $0.77700 \pm 0.119246^{\mathrm{a}}$ \\
9. Laser alone group & $0.77725 \pm 0.112398^{\mathrm{a}}$
\end{tabular}

${ }^{\mathrm{a}} \mathrm{p}>0.05 ;{ }^{\mathrm{b}} \mathrm{p}<0.01$

5637 cells, respectively, and then incubated for an additional $2 \mathrm{~h}$. Following a change of the culture medium, the cells were irradiated with $4 \mathrm{~J} / \mathrm{cm}^{2}$ of laser light at a wavelength of $650 \mathrm{~nm}$. The cells were then harvested with trypsin without EDTA, centrifuged at $2000 \mathrm{rpm}$ for $5 \mathrm{~min}$, and washed twice with ice-cold PBS. After the washes, the cells were re-suspended with $500 \mu \mathrm{l}$ Binding Buffer $(50 \mathrm{mM}$ HEPES, $700 \mathrm{mM} \mathrm{NaCl}$, $12.5 \mathrm{mM} \mathrm{CaCl}_{2}, \mathrm{pH} 7.4$ ) mixed with $5 \mu \mathrm{l}$ Annexin V-FITC and $5 \mu \mathrm{l}$ propidium iodide, incubated for $10 \mathrm{~min}$ in the dark, and then immediately analyzed by flow cytometry. Treatment with chlorophyllin e 4 alone or $4 \mathrm{~J} / \mathrm{cm}^{2}$ laser light alone were included as control groups.

Confocal laser scanning microscopy (CLSM). T24 and 5637 cells were cultured on coverslips placed in Petri dishes with RPMI-1640 culture medium. When cells reached $80 \%$ confluence, the media was removed, chlorophyllin e4 was added to the dishes, and the cells were incubated for $5 \mathrm{~h}$. The cells were then incubated for $30 \mathrm{~min}$ with 100 or $150 \mathrm{nM}$ of MitoTracker ${ }^{\circledR}$ Green Probe, respectively. After incubation, the staining solution was replaced with fresh culture media and observed by CLSM (Olympus FV300, Japan). The excitation wavelength used for chlorophyllin e4 was $405 \mathrm{~nm}$, and the fluorescence excitation 


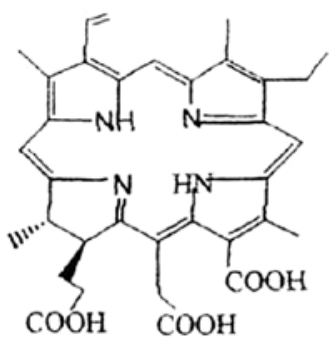

Chlorophyllin e6

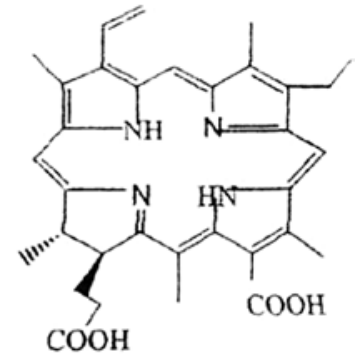

Chlorophyllin e4
Figure 1. Chemical structures of chlorophyllin e6 and e4.

\section{Effect of chlorophyllin e4 on T24 cells}

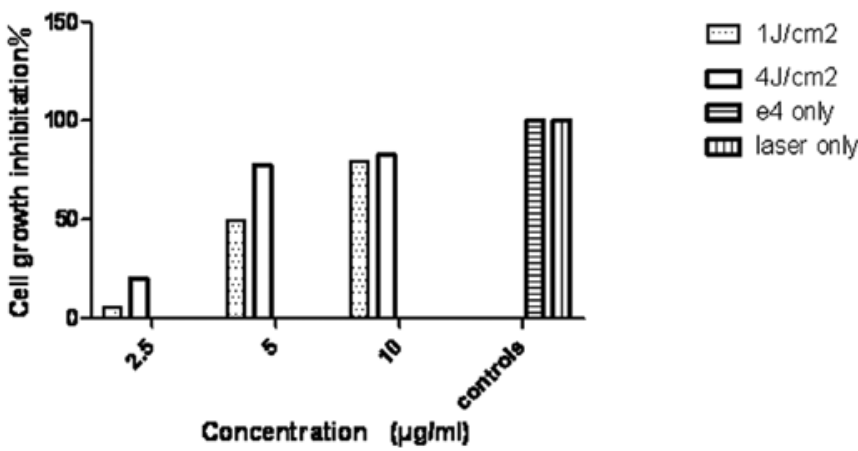

Figure 2. Phototoxicity of chlorophyllin e4 against T2 4 cells. The control cells were treated with $10 \mu \mathrm{g} / \mathrm{ml}$ of chlorophyllin e 4 only or exposed to $4 \mathrm{~J} / \mathrm{cm}^{2}$ laser light only.

and emission wavelengths of MitoTracker Green Probe were 488 and $516 \mathrm{~nm}$, respectively.

Statistical analysis. Statistical analysis was performed based on Analysis of Variance (ANOVA). The results were recorded as mean value \pm standard error of the mean (SEM). $\mathrm{P}<0.05$ was considered significant and all experiments were conducted at least 3 times.

\section{Results}

Cell viability of T24 and 5637 cells after PDT. The photodynamic effect of chlorophyllin e4 against human T24 and 5637 cells was determined using the MTT assay. Tables I and II show the OD values of each group detected at a $490 \mathrm{~nm}$ wavelength. The growth inhibition rate was calculated with the formula: (OD value of cell control group - OD value of treatment group)/OD value of cell control group. Figs. 2 and 3 show the growth inhibition rates after chlorophyllin e4-mediated PDT.

A statistically significant difference was observed in T24 cells in treatment groups 3, 4, 5, 6, and 7 compared to the control groups $(\mathrm{P}<0.01)$; however, treatment group 2 did not show any difference from the control groups ( $\mathrm{P}>0.05$; Fig. 2). In 5637 cells, a significant difference was observed between treatment groups 4, 5, 6, and 7 and the control groups $(\mathrm{P}<0.01)$, while the difference between treatment groups 2 and 3 and the controls was not significant $(\mathrm{P}>0.05$; Fig. 3 ).

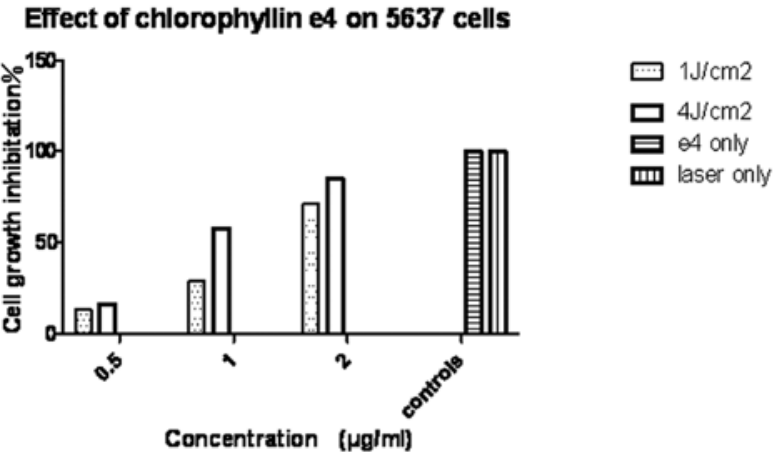

Figure 3. Phototoxicity of chlorophyllin e 4 against 5637 cells. The control cells were treated with $10 \mu \mathrm{g} / \mathrm{ml}$ of chlorophyllin e 4 only or exposed to $4 \mathrm{~J} / \mathrm{cm}^{2}$ laser light only.

In T24 cells, treatment with $2.5 \mu \mathrm{g} / \mathrm{ml}$ of chlorophyllin e4-mediated PDT resulted in only 6.1 and $20.03 \%$ cell death at light doses of 1 and $4 \mathrm{~J} / \mathrm{cm}^{2}$, respectively (Fig. 2). However, a concentration of $10 \mu \mathrm{g} / \mathrm{ml}$ of chlorophyllin e4 appeared to be an effective dose, which induced a remarkable 79.32 and $82.43 \%$ cell death with light doses of 1 and $4 \mathrm{~J} / \mathrm{cm}^{2}$, respectively. Treatment with $5 \mu \mathrm{g} / \mathrm{ml}$ of the compound resulted in 49.77 and $77.38 \%$ cell death with 1 and $4 \mathrm{~J} / \mathrm{cm}^{2}$ of PDT, respectively. The situation was similar in 5637 cells (Fig. 3). Treatment with $500 \mathrm{ng} / \mathrm{ml}$ of chlorphyllin e4 and PDT induced only $13.39 \%$ and $16.61 \%$ cell death at light doses of 1 and $4 \mathrm{~J} / \mathrm{cm}^{2}$, while a concentration of $2 \mu \mathrm{g} / \mathrm{ml}$ and PDT induced 71.20 and $85.06 \%$ cell death, respectively. No cell death was observed in either control groups.

Apoptosis analysis by Annexin-V/PI flow cytometry. Chlorophyllin e4-induced PDT remarkably induced $32.04 \pm 1.3 \%$ and $45.33 \pm 1.7 \%$ apoptosis in T24 and 5637 cells, respectively. This was significantly higher than the T24 and 5637 cell control groups $(\mathrm{p}<0.01)$, which demonstrated only $3.77 \pm 0.3 \%$ and $5.64 \pm 0.7 \%$ apoptosis, respectively (Fig. 4). The chlorophyllin e4 alone group showed $4.45 \pm 0.1 \%$ and $7.95 \pm 0.6 \%$ apoptosis in the T24 and 5637 cells, respectively, while the laser alone group showed only $3.47 \pm 0.3 \%$ and $7.23 \pm 0.4 \%$ apoptosis, respectively (Fig. 4).

Spectral analysis of chlorophyllin e4. We also conducted a spectral analysis of chlorophyllin e4. We found that chlorophyllin e4 has a strong absorption peak at wavelengths 665.5 , 604.5, 505.5, and $405 \mathrm{~nm}$ (Fig. 5). Since the $405 \mathrm{~nm}$ absorption peak of chlorophyllin e 4 was the strongest, we chose this wavelength as the excitation laser channel during CLSM. We also considered the organization penetration of the excitation laser. Since the penetration depth is proportional to the wavelength, and the excitation wavelength for PDT is usually chosen near the wavelength of the absorption peak, we chose $650 \mathrm{~nm}$ as the excitation wavelength for the MTT and flow cytometry assays.

Intracellular distribution of chlorophyllin e4. We next analyzed T24 and 5637 cells co-incubated with chlorophyllin e4 and the MitoTracker Green Probe by CLSM at $405 \mathrm{~nm}$ and $488 \mathrm{~nm}$ wavelength channels, respectively. As shown in Fig. 6, chlorophyllin e 4 emitted red fluorescence light that was excited by the $405 \mathrm{~nm}$ wavelength channel in both T24 and 5637 cells (Fig. 6c 

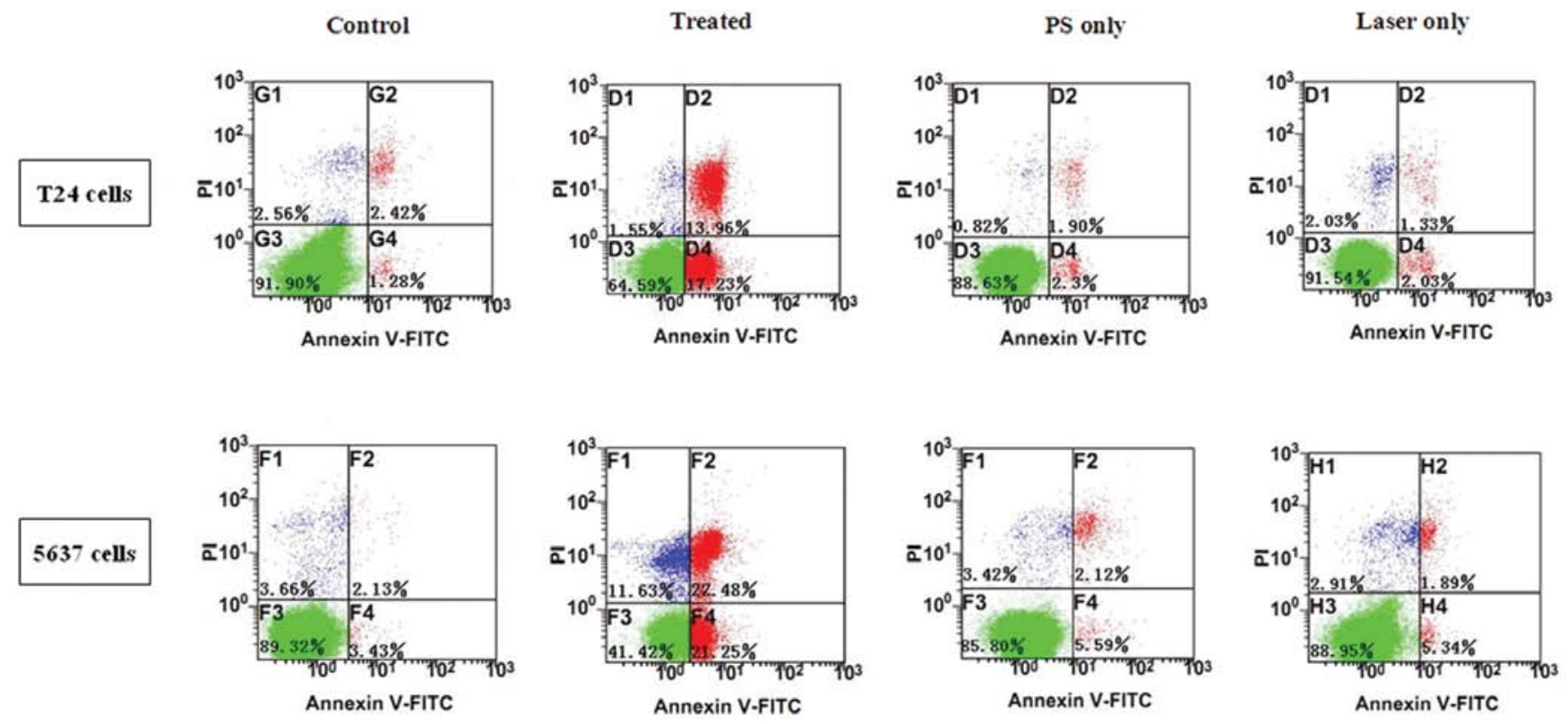

Figure 4. Photodynamic effect of chlorophyllin e4 on apoptosis in T24 and 5637 cells. Cell control group, treatment group, chlorophyllin alone, and laser alone. First quartile: necrosis rate; second quartile: late apoptosis rate; third quartile: normal cell rate; and forth quartile: early apoptosis rate.

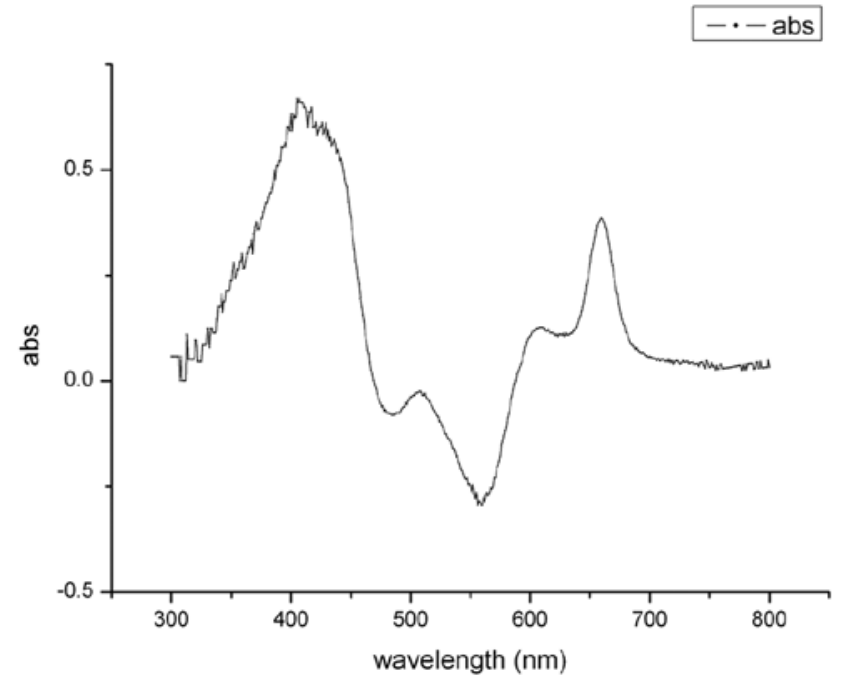

Figure 5. Absorption spectrum of chlorophyllin e4.

and g, respectively). The MitoTracker Green Probe, which specifically stained mitochondria and emitted green fluorescence light that was excited by the $488 \mathrm{~nm}$ wavelength channel, was also found to be restricted to the cytoplasm in these cells (Fig. 6b and f, respectively). An overlay of the chlorophyllin e4 and MitoTracker Green Probe images showed that the signal distribution for both markers was almost identical in both T24 and 5637 cells (Fig. 6d and h, respectively).

\section{Discussion}

Raab et al first described the fatal effects induced by the combination of visible light and acridines on Paramecium at the beginning of the 20th century (9). They named this photochemical phenomenon as 'photodynamic action' or 'chemically sensitized phototoxicity $(10,11)$. Today, several countries have already approved PDT for the clinical treatment of superficial bladder cancer (12-14).

The haematoporphyrin derivative (Photofrin ${ }^{\circledR}$, USA) is the first-generation PS and was approved for clinical use in Canada in 1993 (11). In addition, the benzoporphyrin derivative monoacid ring $\mathrm{A}$ (BPD-MA) and 5-aminolevulinic acid (ALA), which have been approved by the U.S. Food and Drug Administration (FDA), are second-generation PS and are now widely used drugs for the treatment of bladder cancer in practice (15).

There are three basic elements in PDT, which includes a PS, laser light, and oxygen. PS is the most important component and restricts the development of PDT (16). Chlorophyllin e4 belongs to the family of chlorophyll derivatives and has the following advantages: i) it is a pure compound with clear chemical and optical properties and can be easily synthesized according to our specifications; ii) it can be easily dissolved in aqueous solutions and maintains strong stability; iii) Chlorophyllin e 4 has an absorption peak of $665.5 \mathrm{~nm}$, which is optimal for PDT use; iv) it shows little toxicity and is rapidly cleared from the body, since chlorophyll is an essential element of the body; v) BPD-MA and 5-ALA are semi-synthetic compounds derived from natural products, and as such, the overall yield is very low and the synthesis cost is very high, whereas chlorophyllin e4 is obtained from abundant crude materials and has a much lower production cost; vi) the chemical structure of chlorophyllin e4 is relative stable, and all of the experiments in this study were performed with visible light, which eliminates the need to conduct PDT in a dark room; and vii) we have applied for patent protection of the compound. Taken together, these distinct advantages implored us to assess the phototoxicity of chlorophyllin e4 against T24 bladder cancer cells.

We used the MTT assay to evaluate the photocytotoxicity of chlorophyllin e 4 on T24 and 5637 cells. In T24 cells, a concentration of $2.5 \mu \mathrm{g} / \mathrm{ml}$ of chlorophyllin e4 did not exhibit photocytotoxicity; however, a dose of $10 \mu \mathrm{g} / \mathrm{ml}$ of the compound 

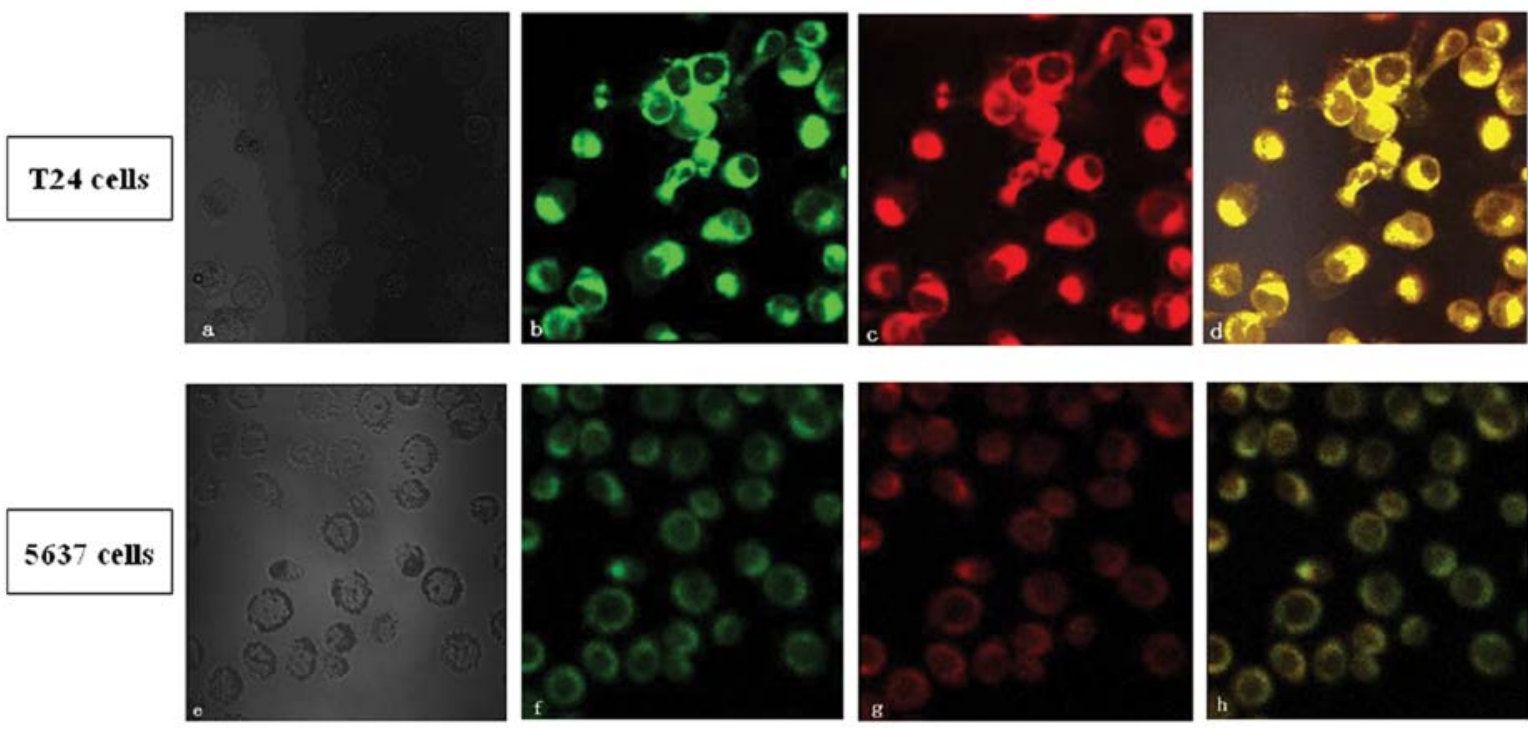

Figure 6. Intracellular fluorescence with CLSM of T24 (a-d) and 5637 cells (e-h). (a and e) Photoplate; (b and f) MitoTracker probe; (c and g) chlorophyllin e4; (d and h) merged images.

was effective and induced $82.43 \%$ cell death at a light dose of $4 \mathrm{~J} / \mathrm{cm}^{2}$. Moreover, a dose of $5 \mu \mathrm{g} / \mathrm{ml}$ of chlorophyllin e 4 caused phototoxicity in T24 cells better than the lower and higher doses, indicating a dose-dependent response. All control groups had no change in cell viability under the same PDT conditions. Similar photocytotoxicity results were obtained in 5637 cells, and an effective dose of $2 \mu \mathrm{g} / \mathrm{ml}$ of chlorophyllin e 4 with PDT of $4 \mathrm{~J} / \mathrm{cm}^{2}$ caused $85.06 \%$ cell death. Together, these data indicate that the photocytotoxicity in these cell lines is dependent on both the PS and light energy doses used.

We also used flow cytometry and CLSM to examine the mechanism of chlorophyllin e4-mediated PDT. The results of the flow cytometry revealed that chlorophyllin e4-mediated PDT caused 32.04 and $54.33 \%$ apoptosis in T24 and 5637 cells, respectively, which was significantly higher than the control groups. These results indicate that apoptosis is the main mechanism of chlorophyllin e4-mediated PDT cell death in these bladder cancer cell types.

During PDT, reactive oxygen species (ROS) are critical factors involved in cell death. The half-life of ROS, which are critical cytotoxic photoproducts, is $<0.04 \mu \mathrm{sec}$, and the radius of action is $\sim 0.02 \mu \mathrm{m}(17,18)$. Therefore, cell damage that is mediated by ROS mainly depends on the PS intracellular distribution. The use of specific organelle probes, such as the MitoTracker Green Probe, which stains mitochondria, together with CLSM allows for identification of subcellular localization $(19,20)$. It is known that mitochondria damage commonly activates apoptosis through different pathways (21). Therefore, we assessed whether the effects of chlorophyllin e4 were associated with mitochondria. The results of CLSM revealed that red fluorescence emitted by chlorophyllin e4 and green fluorescence emitted by MitoTracker Green Probe had an almost identical distribution. Moreover, the overlaid images showed co-localization of the MitoTracker Probe and chlorophyllin e4, suggesting that this compound exerts its effects in the mitochondria.
In conclusion, this is the first study to report chlorophyllin e4 as a potential and effective PS in vitro. Based on our preliminary data, we hypothesize that chlorophyllin e4-mediated PDT occurs by damaging mitochondria and inducing apoptosis, which was observed in the T24 and 5637 human bladder cancer cell lines. These promising results suggest that chlorophyllin e4 is worthy of further investigation, including performing animal studies and exploring its potential application in the management of human superficial bladder cancer.

\section{References}

1. Parkin MD, Bray F, Ferlay J, et al: Global Cancer Statistics, 2002. CA Cancer J Clin 55: 74-108, 2005.

2. Jennal A, Siegel R, Ward E, et al: Cancer Statistics, 2008. CA Cancer J Clin 58: 74-96, 2008.

3. Sylvester RJ, Van der Meijden APM, Oosterlinck W, et al: Predicting recurrence and progression in individual patients with stage Ta T1 bladder cancer using EORTC risk tables: a combined analysis of 2596 patients and seven EORTC trials. Eur Urol 49: 466-477, 2006.

4. Jemal A, Siegel R, Ward E, et al: Cancer Statistics, 2009. CA Cancer J Clin 59: 225-249, 2009.

5. Garcia JA and Dreicer R: Systemic chemotherapy for advanced bladder cancer: update and controversies. J Clin Oncol 24: 5545-5551, 2006

6. Arianayagam R, Arianayagam M and Rashid P: Bladder cancercurrent management. Aust Fam Physician 40: 209-213, 2011.

7. Triesscheijn M, Baas P, Schellens JHM, et al: Photodynamic therapy in oncology. Oncologist 11: 1034-1044, 2006.

8. Juarranz A, Jaén P, Sanz-Rodríguez F, et al: Photodynamic therapy of cancer. Basic principles and applications. Clin Transl Oncol 10: 148-154, 2008.

9. Raab O: Ueber die Wirkung fluorescirender Stoffe auf Infusorien. Z Biol 39: 524-527, 1900

10. Dougherty TJ: An update on photodynamic therapy applications. Clin Laser Med Surg 20: 3-7, 2002.

11. Kudinovaa NV and Berezov TT: Photodynamic therapy of cancer: Search for ideal photosensitizer. Biochemistry (Moscow) Supplement Series B: Biomedical Chemistry 4: 95-103, 2010.

12. Kausch I, Doehn C and Jocham D: Recent improvements in the detection and treatment of non-muscle-invasive bladder cancer. Expert Rev Anticancer Ther 6: 1301-1311, 2006. 
13. Svatek RS, Kamat AM and Dinney CP: Novel theraputics for patients with non-muscle-invasive bladder cancer. Expert Rev Anticancer Ther 9: 807-813, 2009.

14. Dindyal S, Nitkunan T and Bunce CJ: The economic benefit of photodynamic diagnosis in non-muscle invasive bladder cancer. Photodiagnosis Photodyn Ther 5: 153-158, 2008.

15. Allison RR and Sibata CH: Oncologic photodynamic therapy photosensitizers: A clinical review. Photodiagnosis Photodyn Ther 7: 61-75, 2010.

16. Juzeniene A, Peng Q and Moan J: Milestones in the development of photodynamic therapy and fluorescence diagnosis. Photochem Photobiol Sci 6: 1234-1245, 2007.

17. Waidelich R: Laser-induced lithotripsy and photodynamic therapy in urology - A short introduction to current laser applications. Med Laser Appl 25: 14-19, 2010.
18. Castanoa AP, Demidova TN and Hamblin MR: Mechanisms in photodynamic therapy: part one - photosensitizers, photochemistry and cellular localization. Photodiagnosis Photodyn Ther 1: 279-293, 2004.

19. Kessel D, Luguya R, Vicente MG, et al: Localization and photodynamic efficacy of two cationic porphyrins varying in charge distributions. Photochem Photobiol 78: 4312-4335, 2003.

20. Olivo M, Lau W, Manivasager V, et al: Florescence confocal microscopy and image analysis of bladder cancer using 5-aminolevulinic acid. Int J Oncol 21: 523-528, 2003.

21. Ali SM and Olivo M: Bio-distribution and subcellular localization of Hypericin and its role in PDT induced apoptosis in cancer cells. Int J Oncol 21: 531-540, 2002. 